Final version:

Hingley, M.K. and Lindgreen, A. (2002), "Marketing of agricultural products: case findings", British Food Journal, Vol. 104, No. 10, pp. 806-827. (ISSN 0007-070X)

For full article, please contact LindgreenA@ cardiff.ac.uk

\title{
Marketing of Agricultural Products: Case Findings
}

\author{
Martin Hingley ${ }^{1,2}$ \\ Harper Adams University College \\ Newport, Shropshire, United Kingdom \\ and \\ Adam Lindgreen, $\mathbf{P h D}^{3}$ \\ Technical University of Eindhoven \\ Eindhoven, the Netherlands
}

Word count: 6.432 (excluding tables, figures, and references)

\footnotetext{
1 Martin Hingley, senior lecturer with Harper Adams University College, United Kingdom. Address for correspondence: Martin Hingley, School of Management, Harper Adams University College, Newport, Shropshire, TF10 8NB, United Kingdom. Email mhingley@ harper-adams.ac.uk. Telephone + 44 - (0) 1952820 280. Fax + 44 - (0) 1952814783.

${ }^{2}$ Both authors contributed equally and have been listed alphabetically. The authors would like to thank the anonymous reviewers for the useful suggestions.

${ }^{3}$ Adam Lindgreen, senior lecturer with the Technical University of Eindhoven, the Netherlands. Address for correspondence: Adam Lindgreen, Avenue du Centre Sportif 45, Bte 8, 1300 Wavre, Belgium. Email Adam_Lindgreen@hotmail.com. Telephone + 32 - (0) 1022 2743. The author would like to thank the Danish Research Academy and the Université catholique de Louvain in Belgium for generous research funding. He is a Visiting Professor with Auckland University of Technology in New Zealand and a Visiting Reader with Harper Adams University College in the United Kingdom.
} 


\title{
Marketing of Agricultural Products: Case Findings
}

\begin{abstract}
This article focuses on the relationship marketing approach to marketing of agricultural products. The article provides specific insights into, and comparisons between, suppliers of two particular agricultural products sectors: in Britain, the fresh produce (fruits and vegetables) sector and, in New Zealand, the wine sector. The article examines the nature of marketing relationships from the perspective of the suppliers in these sectors and their relationships, networks, and interactions with importers and retail buyers in the food and beverage industry. The research methodology is qualitative and inductive in nature and utilises multiple cases: Interpretation is firstly through content analysis of each individual case in order to identify important themes, clusters, and patterns in the research data and secondly through across-case analysis. Investigated marketing issues include the following ones: (1) nature of relationship marketing, (2) implementation of relationship marketing, and (3) monitoring and measurement of relationship marketing.
\end{abstract}

Keywords: Agricultural products; Case method; Implementation of marketing practices; Monitoring and measurement of marketing practices; Nature of marketing practices; Relationship marketing.

\section{Introduction: A Relational Approach to Marketing}

In the 1980s and certainly in the 1990s, relationship marketing gained ground in marketing as a response to an increasing dissatisfaction with the 'classical' model of marketing based upon 
discrete marketing exchanges through manipulation of the marketing mix (i.e., the 4Ps: product, price, promotion, and place). In Table 1, the two approaches to marketing have been compared and contrasted.

\section{[Take in Table 1]}

There are two, or more, actors in a business relationship: the buyer who seeks to satisfy a need and the seller who proposes an offer. In transaction marketing, buyers seek solutions to a generic need and sellers present a generic offer. In relationship marketing, on the other hand, sellers have developed a unique offer because buyers want to satisfy a particular need.

For a long time, the industrial marketing literature and marketing channels literature characterised the interaction between actors, who are engaging in transactional marketing exchanges, in terms of power, conflict, and control. With the introduction of relational marketing exchanges, the interaction between actors is described using constructs such as trust, commitment, and co-operation. This means that an actor, who is involved in relational marketing exchanges, does not behave opportunistically and does not seek to influence the decisions or actions of the other actor (e.g., Anderson and Narus, 1990; Dwyer, Schurr and Oh, 1987; Mohr and Spekman, 1994; Morgan and Hunt, 1994).

Since marketing exchanges are independent and discrete in transaction marketing, actors tend to focus on short-time economical gains. This is less true in relationship marketing because marketing exchanges now are episodic, in a series of episodes within a long-term buyer-seller relationship. Long-time gains such as social bonding and the prospect of future interaction and gains, therefore, become much more relevant. This is also the reason why the structural 
attributes of the relational market place are characterised in terms of relationships, networks, and interactions (as opposed to an anonymous and efficient transactional market place).

Relationship marketing is, however, sourced from an eclectic mix of influencers, not only from academics in marketing and management disciplines but also from practitioners in business organisations (e.g., Brodie et al., 1997; Buttle, 1996; Möller and Halinen-Kaila, 1998; Sheth and Parvatiyar, 2000). This has resulted in some 'confusion' of what relationship marketing really is. To some people, relationship marketing seeks to operationalise the acknowledged view of marketing and concerns servicing and satisfying existing customers through long-term, close, interactive, and collaborative relationships, networks, and interactions that are mutually beneficial and profitable (e.g., Berry, 1983; Dodge and Fullerton, 1997; Jüttner and Wehrli, 1994; Palmer, 1994). To others, there has been a real a paradigm shift in marketing (e.g., Grönroos, 1994; Gummesson, 1999; Sharma and Sheth, 1997). The long-term outcome of the relational approach to marketing has been seen as partnerships or alliances (e.g., Vlosky and Wilson, 1997).

Although the relational approach to marketing has attracted much interest in marketing, some researchers have argued that relationship marketing is underdeveloped in vertical supply chains and called for further investigations (e.g., Fontenot and Wilson, 1997; Vlosky and Wilson, 1997). Indeed, it has been noted that there is still little consistent theory of how relationship marketing fits into the greater marketing landscape (Collins, 1999; Lindgreen and Crawford, 1999; Palmer, 1998). The article seeks to examine this problem.

The food and beverage industry is currently undergoing concentration in most parts of the supply chain through backward vertical integration initiated by powerful multiple retail 
buyers (Galizzi and Venturini, 1996; Hughes, 1994). Acquisitions, mergers, and internal restructuring have transformed the competitive environment, driven by a complex mix of technological, socio-economic, and political changes (Traill and Pitts, 1998). The scale and pace of restructuring in this industry vary between product categories and supply chain levels, but the overall trend is toward many sectors in the industry being dominated by a few large corporations operating on a European or even global scale. This process could have a possible deep impact on the relationships, networks, and interactions between sellers and buyers, which makes the industry interesting for a research point of view.

\section{Research Issues}

To gain preliminary insight into the marketing practices, which are at play in the food and beverage industry, it was decided to examine how managers have understood relationship marketing and how, if at all, relationship marketing has been implemented, monitored, and measured. These research issues were believed to be real important ones. Despite the fact that the term 'relationship marketing' was introduced more than 15 years ago (Berry, 1983) there is still little consistent story of how relationship marketing fits into the greater marketing landscape (e.g., Collins, 1999; Harker, 1999; Möller and Halinen-Kaila, 1998; Palmer, 1998). According to the Marketing Science Institute (1999), one of the pressing priorities in marketing is to identify marketing activities for building relationships and to quantify the effectiveness of customer loyalty initiatives.

At this stage, different types of marketing activities have been suggested as being part of a relationship marketing programme: customising product and market communications, caring for customers, partnering with customers, internal marketing, and loyalty programmes (e.g., 
Brodie et al., 1997; Snehota and Söderlund, 1998). According to some researchers, relationship marketing is only one of these marketing activities but other researchers argue that a marketing programme, which is more relational, would employ a number of marketing activities in addition to traditional marketing (i.e., the 4Ps). That is, marketers are employing a pluralistic approach to marketing (e.g., combining traditional marketing with network marketing) instead of going for one particular marketing activity (e.g., traditional marketing, database marketing, or product customisation). (See, for example, Brodie et al. (1997) and Lindgreen and Pels (2001) for a discussion of this issue.) With regard to the measurement of relationship marketing, Gummesson (1998) has noted that marketers rarely link expenses due to the building of relationships, networks, and interactions with returns on such a programme. Table 2 summaries the different views on relationship marketing as suggested in the marketing literature.

[Take in Table 2]

\section{Research Methodology}

The phenomenon of relationship marketing is complex and dynamic (Lewin and Johnston, 1997; Wilson and Vlosky, 1997), which is why the appropriate research methodology was believed to be qualitative and inductive case studies, reflecting an exploratory approach to building theories.

A multi-case, multi-site approach was used to allow for increased generalisability and, to some extent, reliability through repetition (Dey, 1993; Miles and Huberman, 1994; Yin, 1994). Semi-structured, in-depth interviews were conducted with 14 cases from supplier 
organisations in the wine sector in New Zealand and 17 from fresh produce supplier and buying organisations in Britain. Fresh produce organisations interviewed included suppliers of products from both domestic and global sources. Interview respondents were invited to express their perceptions with regard to the nature, implementation, and monitoring of business relationships. On average, each interview lasted two hours. In addition to interviews, case evidence also included existing marketing intelligence in, for example, trade journals and in the business and financial press. Other case evidence included archival data such as annual reports and business documents dealing with different aspects of production, logistics, marketing, sales, and finance. For reasons of confidentiality, the identities of case organisations are expressed anonymously.

The cases were first analysed individually (i.e., within-case analysis) before an analysis across first two, then three, four etc. cases was carried out. This procedure meant that the improvement of the resulting theory happened through cycles of data collection and data analysis that continued until theoretical saturation (Eisenhardt, 1989; Lincoln and Guba, 1985; Lindgreen, 2001).

\section{Case Findings}

Preliminary findings of the research will be discussed relative to the three investigated marketing issues (1) nature of relationship marketing, (2), implementation of relationship marketing, and (3) monitoring and measurement of relationship marketing. At the end of this section, Tables 3 and 4 summarise the research findings for the two sectors. 


\section{Nature of relationship marketing}

Power dependency: There is evidence to suggest that the retailer and not the supplier ultimately dictates the balance of power (in, for example, decision making) in the British fresh produce sector. This is evidenced in the following text unit:

"A partnership between a supplier and a multiple retailer is like a ballerina dancing with a bear."

(Retailer 3)

Some suppliers expressed their concern about the retailers' power fearing that the power could be used against them and that the power is counter-productive to a business relationship that is mutual for both parties. These suppliers found themselves to be pragmatic, though, believing that there are benefits to be realised from a close business supplier-retailer relationship, and this belief is the reason why these suppliers continue to stay in this type of relationships. Other suppliers in the British fresh produce sector argue, however, that business relationships, which would seem to favour one partner in terms of power influence, are, in fact, more equal than what might first appear. Although powerful, retailers rely on their suppliers and more so than if they had been trading on the open fresh produce market on a daily basis. This is evidenced in the following text unit:

\footnotetext{
"They [i.e., the supermarkets] are not producing, they are only selling to the consumer. We need them [to sell it]. But they are [only] as good as their raw material.” (Supplier 1)
}

In the case of the New Zealand wine sector the vineyards tend to offer their wines for several markets in order to reduce being dependent on a single market. Most of the vineyards also expressed their concern for not becoming dependent on big retailers, as echoed in the following text unit: 
"We are to small to get into [producing for the retailers' private-labelled wines] but even if we were bigger I still would not do it because you lose your own brand identity. The brand name of our wine ... is too precious." (Vineyard 1)

One path that the smaller vineyards have followed is to ensure that the size of the importer is comparable to that of the retailer. For example, Vineyard 2 has chosen Wine importer 2 as the British importer of its wines because Wine importer 2 is the biggest British importer of New World wines and thus is seen as better able to deal with the big retailers:

\footnotetext{
"The nature of the market is dominated by supermarkets ... The scale of those chains to effect our business is just massive." (Vineyard 2)
}

Another path has been to reach mutual agreement instead of one-way dictation, as evidenced in the following text unit:

\footnotetext{
"Through a series of meetings this year, we began to work towards that [i.e., partnership] as an objective for both companies and we began to talk about the types of things that needed to be agreed between us and needed to be stated up front in a very clear fashion so that both sides understood their obligations." (Vineyard 2)
}

In conclusion, suppliers in the British fresh produce sector have accepted the imbalance in power because they have exclusivity for their products (see below) and an opportunity for increasing their sales volume to the particular retailer. In the New Zealand wine sector, on the other hand, vineyards are not ready to accept such an imbalance in power and have gone to great length in designing appropriate marketing approaches, such as supplying to many different markets and to big importers.

Exclusivity: Retailers increasingly prefer exclusive or dedicated supplies of fresh produce from what they term 'preferred suppliers', and there is evidence to suggest that the suppliers 
appreciate that they are being singled out for special treatment. Exclusivity is believed to result in greater economies of scale and reduction of search times. This is echoed in the following text unit:

“It [i.e., exclusivity] increases everybody's purchasing power enormously. It means that you can have more and more strategic discussion, placing larger and larger chunks of your business with people who are more and more dedicated towards [Retailer 3]." (Retailer 3)

A further reason for seeking exclusivity is to deprive retail competitors of a particular product source or product advantage and thereby achieve further market differentiation in matters of quality, source continuity, confidentiality, and innovative new product development. Exclusivity, however, is difficult to implement 100 per cent, as suppliers want to market their entire fresh produce output and not only that of superior quality products required by a principal retail customer. To overcome this problem, suppliers have set up so-called 'dedicated lines'. With these product lines, the products of superior quality are being produced for the principal retail customer, but arrangements allow the possibility of an outlet for second quality product through less close partners or alternative distribution outlets (through, for example, fresh produce wholesalers or discount stores). Some suppliers will have several dedicated lines, involving exclusivity arrangements with different retailer customers.

The New Zealand vineyards will often require that their importer does not carry similar wines from the same country (e.g., no other Chardonnays than the ones from a particular vineyard) so that the importer can give them full attention:

\footnotetext{
"[Vineyard 7] are the only New Zealand winery that we work with ... I am not interested in representing other wineries." (Wine importer 7)
} 
“They [i.e., Wine importer 3] also do not have many other table wines as part of their distribution portfolio ... A small portfolio, I think, is very important.” (Vineyard 3)

Trust and commitment: The presence of trust was found to be important in both the fresh produce and the wine sectors: All parties thus recognised trust as being significant to an efficient working relationships where, for example, information on market movements and changes in marketing strategies are readily exchanged. An issue for fresh produce suppliers is, however, that commitment is often one way on their part with regard to their dealings with buyers, who often withhold commitment (in the form of sharing investment costs and through lack of any formal written agreement with regard to partner status). Further to this, a number of retailer buyers fear commitment on their part, which results from fear of loss of power and control over suppliers.

Two different types of trust were found to be present in the New Zealand wine sector: trust in credibility and trust in benevolence. Trust in credibility includes awards at wine competitions; prominent position within sector; in-depth knowledge of sector; and affiliation with third parties. This is evidenced in the following text unit:

\footnotetext{
"He is somebody who has historical position in the business and has a very high level of wine expertise and has relationships and the understanding of the wine business in the UK ... Competitions, gold medals and trophies give you opportunity to advertise and persuade the consumer they should choose your wine above somebody else's." (Vineyard 2)
}

With regard to the latter one, frequent forthright communication; importer locates retailers for exporter; and business deal closed by shaking hands lead to trust in benevolence:

\footnotetext{
"I think that [communication] is pretty open and frank and honest ... It is important that we trust each other in that respect." (Wine importer 5)
} 
"I think that it is important for the producer that its distributor should be able to put his wines into the right client base in the UK. (Wine importer 7)

Satisfaction and social bonding: An important issue in the development of a relational approach is the establishment of a good workable social context. A social relationship is believed to be necessary and, for some parties, advantageous. Attitudes to social relationships between fresh produce and wine supply chains differ, though. In the fresh produce sector, social contexts are desirable, but normally only when restricted to a business context. Business socialising and entertaining is generally seen as unacceptable and a thing of the past. In the wine sector, socialising is much more prevalent and even extends to outside of a workplace environment. Differences here relate to the nature of product; whereas wine and wine appreciation is an acquired art and science, fresh produce - although requiring technical appreciation - is a matter of product trading and discussions are confined largely to availability and quality. Fresh produce retail buyers are reluctant to 'let down their guard' in social situations; furthermore, they may spend considerably less time in post that an equivalent wine buyer. A fresh produce-buying role may be a stepping stone to career progression even after only 18 months to two years of duration. Consequently there is less time and inclination toward social interaction.

\section{Implementation of relationship marketing}

Product driven or market driven: The question of whether an organisation should be driven by the product or the market is important. Researchers have argued that the market should drive companies (e.g., Capon and Glazer, 1987; Glazer, 1991; Jaworski and Kohli, 1993). However, recently Baker and Sinkula (1999) and Dutta et al. (1999) have theoretically 
proposed that the product drives some organisations. For both sectors the quality of the product was found to be important.

In the case of the British fresh produce sector one of the main objectives of the retailers is to reduce inconsistencies in the quality of the products and in their availability and delivery. These inconsistencies are often due to seasonal reasons. A relationship approach has reduced production orientation in fresh produce and such inconsistencies are being evened out by improved joint supply chain planning with regard to the quality of the products and in their availability and delivery. In fresh produce the issue of supplier branding is much less significant than that with New Zealand wines, brand identity lies almost exclusively with the retailer customers. Suppliers, therefore, have virtually no control over the identity of their products in store. The evidence would thus seem to suggest that market orientation is predominant in fresh produce, but this is manifested in product and service quality rather than branding issues. However, although fresh produce suppliers have little opportunity to market products under their own identity, partnership arrangements with retailers allow a close working relationship with regard to product development and marketing. Further, suppliers have direct access to the market (albeit under a retailer rather than their own brand identity) and this does facilitate an innovative and market-driven business environment.

In the case of the New Zealand wine sector all vineyards must be members of the Wine Institute of New Zealand that sets up the minimum standards that a vineyard must meet in order to be able to export wines. The idea is to protect the 'Produce of New Zealand' brand from inferior-producing vineyards. The emphasis on reaching a superior wine quality is in accordance with what a number of managers argued. Because the process of producing wines is long (from planting of vines over fermentation of grapes to shipping of wine cases) it 
becomes very difficult to be driven by current changes in the market. These vineyards complement the best winemaking traditions from the Old World with the latest technical innovations. This belief is echoed in the following text unit:

\footnotetext{
"[Being market driven] does not happen with wine. Those vineyards take a number of years to crop and if you want to expand you have got to acquire land and wait seven or eight years. Inevitably, you are constrained by what you have made." (Vineyard 4)
}

Other managers argue, however, that because the market has become extremely competitive the vineyards must adjust their production to what the customers are asking for. For example, these vineyards invest in the planting of other vine varieties or they develop special labels or particular brands for certain markets. This is evidenced in the following text unit:

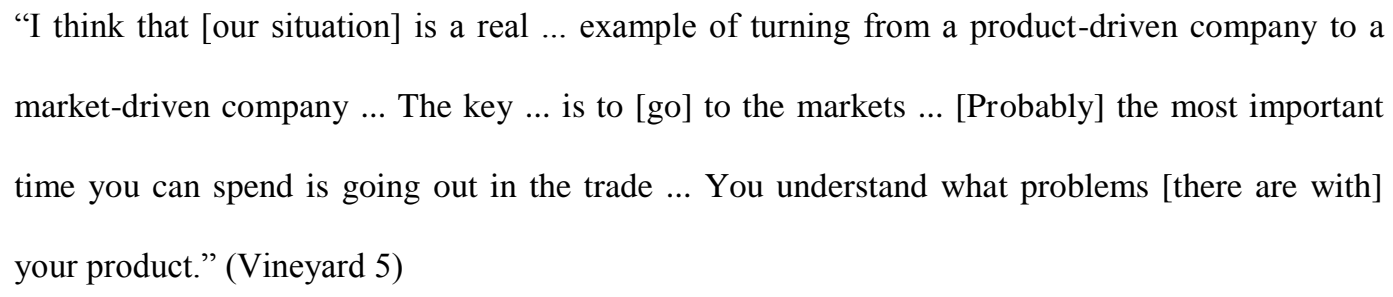

As described, the Wine Institute of New Zealand exercises great control - not only with regard to the standard of wines but also in terms of the generic export marketing strategies that most of the vineyards partake in. It is interesting to notice, however, that the vineyards still deal with the importers on an individual basis. This has been illustrated in Figure 1 where - for simplicity reasons - all the vineyards are depicted as dealing with the same importer, which is not necessarily the case in real life.

\section{[Take in Figure 1]}

In the British fresh produce sector, there is no one central body that has responsibility for industry marketing. However, in other ways the situation is similar to the one in New 
Zealand. There is a trend for retailers to cut out the traditional middleman (wholesaler or import agent) and to source direct from producers. This invokes the network approach to the food industry (Brookes, 1995; Fearne and Hughes, 1999; Wilson, 1996) whereby retail buyers of fresh produce use preferred grower-packer organisations to act as feeders for overseas supply or small scale/specialist growers in addition to the sourcing of own homeproduced and packed product. This approach is a parallel to the hub and spoke analogy of Sheth and Sharma (1997) with grower-packers acting as the hub on behalf of their retail customers and with spokes of supply lines feeding into the grower-packer from Britain and world-wide sourcing.

Product customisation: In the fresh produce sector there is great pressure to differentiate in a fiercely competitive market. Innovative and often expensive product development (necessary to provide this differentiation) is best derived from exclusive relationships where a greater degree of control and privacy can be achieved. This innovation and product customisation is often dealt with through production sites dedicated to exclusive customers. It is, as discussed earlier, beneficial for retailers to deal with fewer exclusive sources. But that also means that retailers are more reliant on these organisations in whom they place a great deal of trust, volume of business and share sensitive new product development details. A further agenda for retailers in seeking exclusivity is to deprive the competition of a particular product source or product advantage and, thereby, achieve further market differentiation in matters of quality, source continuity, confidentiality, and innovative new product development.

Some vineyards offer only a range of standard wines whereas others customise their wines, such as designing special labels (e.g., for the British retailer Tesco) or particular brands for a certain market. The following text units highlight these differing views: 
"We have a standard product range." (Vineyard 6)

"[We] introduced [a] second label to sell mainly on [name of place withhold for confidentiality reasons] called [name of wine withhold for confidentiality reasons] so it has become a very strong second brand and we do not export that [label]. It is just sold locally." (Vineyard 1)

Marketing communications: Players in both sectors were increasingly employing communications as a competitive marketing tool. In addition to the generic export marketing strategies already mentioned, vineyards in New Zealand seek press coverage in international wine journals thus hoping for independent endorsement of their wines. Some vineyards also send out newsletters or have their own Web sites that allow customers to learn more about the vineyard and its wines, but also to place orders through the vineyard or its importer(s). At times, the vineyards participate in in-store wine tasting. One vineyard in particular expressed its concern of not having its brand being mistaken for yet another New Zealand wine and explained that it did not partake in the marketing activities of the Wine Institute of New Zealand. At a higher level, communications are between the vineyards and their importers. Thus regular meetings take place between the vineyard and the importer, i.e. meetings between different employees at different levels within the organisations. The regularity and formality of the meetings, which can cover production, inventory, advertising, and sales, will depend upon the size of the business entities with the meetings tending to be more formal the bigger the business entities. For the smaller business entities informal meetings are on an $a d$ hoc basis.

In the British fresh produce sector, marketing communications are, once again, in the hands of the retailer and endorse product under the retailer's own brand. However, there is some evidence of a move toward on-pack identity and joint branding with some specific products, 
where a product may offer some unique produce advantages or characteristics. Additionally, retailers are promoting their links with partner suppliers in the form of in-store poster promotions that name, for example, a particular grower and the nature of the product and relationship with the retailer. This theme is pursued through other promotional routes, such as features in retailer in-house magazines and lifestyle magazines.

With regard to communications between suppliers and buyers of fresh produce - and in common with the wine sector - there is evidence of regular meetings between suppliers and buyers and between cross-functional personnel. Frequency of face-to-face meeting and other contact is often dependent on the closeness of the relationship where, once again, meetings with larger suppliers tend to be more frequent and planned. However, for smaller fresh produce businesses, it does not mean that these necessarily receive less attention. Such organisations may bring unique product and service innovations and, therefore, warrant an equally high level of contact. In fresh produce frequency and quality of communication is less about organisation size and more about the provision of closer access to preferred status suppliers.

A further area of importance in marketing communications in the fresh produce sector is that of electronic communications. Order and invoice data is quite routinely transmitted and processed via closed user data transfer systems, such as with electronic data interchange. However, the use of electronic communications as a two-way relationship tool is still in the development stage with buyers only gradually allowing on-line access to information (of, for example, retail sales data) to preferred suppliers/partner suppliers. Although there are tremendous advantages of using electronic communications as a labour and time saving device, there is evidence that electronic communication has reduced both the important 
human interface and bargaining power of the supplier, where buyers deliver electronic messages as a fait accompli rather than a tool for discussion, information exchange, or negotiation:

\footnotetext{
"They [i.e., Retailer 4] are getting more and more to rely on e-mail and things like that, sooner than the verbal approach. We are finding it is more difficult to actually negotiate with supermarkets because of this method of approach.” (Supplier 5)
}

Customer partnering: Although a vineyard in New Zealand does not typically partner with the importers it will co-operate with them. Specifically there will be contractual agreements on how many wine cases the vineyards will have to deliver to the importers who have committed themselves to the retailers or the specialists. Only one vineyard was found to have entered into a formalised partnership with its preferred importer in Britain.

With regard to the British fresh produce industry, all retailers interviewed are moving toward, or have already established, a relational approach in their dealings with suppliers. What emerged from the adoption of this approach are moves by some retailers to formalise the relationship between supplier and buyer within partnership documents. Such documents define the nature and responsibilities of the relationship between signatories. In fresh produce there is a movement toward a greater formalisation of exchange relationships. Increased planning allows managers to place events in a more manageable and measurable historical context and, thereby, to make more informed decisions. However, views are divided as to the meaning and usefulness of formal partnership documentation, beyond less formal and ad hoc agreements. 


\section{Monitoring and measurement of relationship marketing}

Monitoring of relationship marketing: For smaller vineyards, the monitoring and measurement of relationship marketing is very limited; for bigger vineyards, both monitoring - in terms of production, logistics, marketing, and sales planning - and measuring - in terms of financial performance reviews - is used more frequently. This is evidenced is the following text unit:

"We are [improving] the effectiveness of the partnerships that we have with our international distributors. ... [We] are implementing a whole bunch of systems and guidelines into our partnerships to ensure that they do operate effectively and [that] both sides have a clear understanding of the mutual objectives and the obligations that each party has to the other." (Vineyard 2)

In such cases, regular meetings take place between the vineyard and the importer (i.e., meeting between different employees at different levels within the organisations); meetings cover production, inventory, advertising, and sales (overall and for individual brands). Both parties can initiate such meetings. The vineyard is responsible for the wine production and for the logistics (transportation of wine cases from New Zealand to the British importer) whereas the importer is responsible for the trading activities in Britain. Both parties are responsible for the marketing activities and carry out different parts of these activities.

In the fresh produce sector, retailers are beginning to formally distinguish between the relative importance of their suppliers and may grade suppliers with respect to performance criteria, which affect the level of treatment that a supplier will receive (in terms of, for example, frequency of meeting). Suppliers are then identified under different grades according to importance to the retailer: 
1. Preferred suppliers.

2. Development suppliers.

3. Transactional suppliers.

Preferred suppliers are first call suppliers of choice, who are allowed a greater closeness to the retailer in terms of access and frequency of meeting. The subject matter for discussion could, for example, be of a production plane other than simply day-to-day operational functions reserved for dealings with transactional suppliers. Development suppliers may be smaller or product-specialist organisations with whom a retailer is hoping to nurture or cultivate a more meaningful relationship.

Additionally, retailers use formalised grading of suppliers as a tool for rationalisation of their fresh produce supply base, where future focus will be on preferred suppliers and others may be identified to be the future casualties of rationalisation:

"We categorise our suppliers into those we hold and those that we squeeze." (Retailer 1)

Measurement of relationship marketing: Some vineyards believe that they profit on having a relational approach to marketing and that they would suffer not having this approach; other vineyards can actually measure an increased profit after having installed such a programme. The profit may be increased retention of one's business parties, as evidenced in the following text unit.

\footnotetext{
"The acid test is, they come back and re-order every year. If they did not like the product or they did not like us, they would not place repeat orders year after year. Virtually all the [Vineyard 7] wine we sell is to customers who have been ordering it over a number of years." (Wine importer
} 7) 
In fresh produce a relationship marketing approach can be a route to very rapid growth for a supplier. The logic behind this is clear. If a retailer rationalises his supply base, this means that the favoured suppliers that remain are likely to see faster growth or, indeed, sudden leaps in turnover of business with that customer. An exclusive supply situation may derive even more spectacular growth:

\footnotetext{
"During the last five years, the business has expanded by 25 per cent a year, from fairly low beginnings. Ten times the turnover in ten years ... 70 per cent of our business is with [Retailer 5] and [Retailer 3] and all the development has had to come from those two major customers." (Supplier 4)
}

It is often the case that small and medium enterprise suppliers realise an explosive growth trajectory as a result of their association with large retail customers rather than the steady incremental growth that they might have expected through serving a broader customer base. As a result, and as evidenced in Blundel and Hingley (2001), partnering between small and medium enterprise organisations and far larger retail buyers can be very successful.

However, relationship development with preferred suppliers has facilitated a major supply chain rationalisation programme in fresh produce with non-partner suppliers de-listed. Volume growth for partner suppliers can consequently be high and is serviced through evolving network formations with the supplier partner at the hub. But there is a downward pressure on profitability even for partner suppliers. In addition, the supplier bears the burden of investment costs. Benefits arising from partnered growth, however, are in the stability of consistent payment from buyers and reduction in supply chain costs associated with serving one or few partner customers. Further, referral business often ensues from partnerships with principal customers. 
[Take in Table 3]

[Take in Table 4]

\section{Conclusions}

Although the term 'relationship marketing' was first introduced more than 15 years ago, more research is needed on identifying activities for building relationships and quantifying the effectiveness of such activities. The research, which the article has reported on, set out to investigate the following marketing issues: (1) nature of relationship marketing, (2) implementation of relationship marketing, and (3) monitoring and measurement of relationship marketing.

Three concepts in particular - power dependency, exclusivity, and trust - were found to be important when characterising business relationships.

Power dependency: Although the largest importers/retailers would seem to hold immense power over the suppliers the findings do suggest that even such relationships are more equal than what might first appear. The reason for this is that the importers/retailers rely on the suppliers who have entered into exclusive trade arrangements with them. Another reason is that some suppliers deliberately have installed a policy of spreading their products over a number of importers/retailers in order not to becoming dependent on a single importer/retailer.

Exclusivity: Suppliers are increasingly entering into exclusive trade arrangements with importers/retailers. A variant of this arrangement is when the supplier requires that the importer/retailer does not carry products that are similar to those of the supplier. If an 
importer/retailer wishes to set up an exclusive trade arrangement he should allow the supplier alternative distribution outlets for second quality products.

Trust and commitment: The findings suggest that trust (i.e., trust in credibility and trust in benevolence) and commitment are important. This is a significant finding for managers because they can shape, for example, both variants of trust. In-depth sector knowledge enhances one actor's trust in the other actor's credibility whilst trust in benevolence depends on the behaviour of both actors and the history of interactions among them. Trust can, therefore, be used as a valuable strategic variable.

With regard to implementing relationship marketing there are a number of interesting findings.

Product driven and/or market driven: Although the fresh produce sector is market driven the suppliers have little direct access to the market and this is why the sector has implemented product and service quality programmes as a means to facilitate an innovative and market-driven business environment. The situation is different in the wine sector: Some managers argue that because the market is extremely competitive the vineyards must be market driven whilst other managers contend that vineyards are, in general, product driven since the process of producing wines is long.

Marketing communications: Both the supplier and the retailer communicate with the end-consumers through, for example, branding, advertising, and in-store promotions. Communication also takes place between the supplier and the importer/retailer and although the recent advancement of electronic communications has allowed for on-line access to important information the findings suggest that it has reduced the important human interface between the actors. 
Actors in both sectors are only now beginning to formally monitor and measure relationship marketing programmes.

Monitoring of relationship marketing: The smaller players in the sectors do little of monitoring marketing programmes whereas the larger players have formal systems in place for productions, logistics, marketing, sales, and finances. The monitoring makes it possible to grade suppliers (or, indeed, importers/retailers) according to their importance.

Measurement of relationship marketing: Among the few figures for measuring marketing programmes were net profit, volume growth, stability, reduced costs, and referral business.

\section{Future Research}

Case studies have often been criticised for providing only little basis for the researchers to generalise their results. But it is important to realise that case studies are generalisable to theoretical propositions and not to populations or universes (Yin, 1994). Each case should ideally be described as broadly as possible so that it will be possible to judge whether or not the case study findings from one contextual setting can be transferred to another contextual setting (Punch, 1998; Yin, 1994). This also means that the essential characteristic of a case study is that the report contains explicit presentations of the key evidence that were used to draw the conclusions. The case study method is, therefore, discursive, and readers often find the lengthy description of results exhausting. Because of that, the major research findings for each of the three investigated marketing issues in this article have been listed and explained thoroughly in Tables 3 and 4. This should help to judge whether, in fact, the findings could be transferred to another setting. However, the strict requirement to space limitations makes it 
impossible to describe the settings in more depth because this would mean that there would be less opportunity for discussing the results.

Future research could examine the following issue: The findings suggest that quality of a relationship between a buyer and seller is determined by such different dimensions as trust in credibility, trust in benevolence, commitment, social bonding, satisfaction, and conflict. Is it possible to operationalise relationship quality, and is it possible to determine what is the impact of relationship quality on the outcome of a buyer-seller relationship of high quality, such as increased customer retention and, ultimately, increased shareholder value? Investigating this would combine two of the marketing issues, namely the nature of relationship marketing and the monitoring and measurement of relationship marketing. Future research could also study how, if at all, buyer and sellers are using electronic communications as a means of improving their business relationships. Do they employ electronic communications on a corporate, business, and/or functional level, and is the communication external and/or internal?

\section{References}

Anderson, J. C. and Narus, J. A. (1990), “A model of distributor firm and manufacturing firm working partnership", Journal of Marketing, Vol. 54, No. 1, pp. 42-58.

Baker, W. E. and Sinkula, J. M. (1999), "The synergistic effect of market orientation and learning orientation on organizational performance", Journal of the Academy of Marketing Science, Vol. 27, No. 4, pp. 411-427. 
Berry, L. L. (1983), “Relationship marketing”, in Berry, L. L., Shostack, G. L. and Upah, G. D. (Eds.), Emerging Perspectives on Services Marketing, American Marketing Association, Chicago, Illinois, pp. 25-28.

Blundel, R. K. and Hingley, M. K. (2001), "Exploring growth in vertical inter-firm relationships: small-medium firms supplying multiple food retailers”, Journal of Small Business and Enterprise Development, Vol. 8, Number 3, pp. 245-264.

Brodie, R. J., Coviello, N. E., Brookes, R. W. and Little, V. (1997), "Towards a paradigm shift in marketing? An examination of current marketing practices", Journal of Marketing Management, Vol. 13, No. 5, pp. 383-406.

Brookes, R. (1995), "Recent changes in the retailing of fresh produce: strategic implications for fresh produce suppliers”, Journal of Business Research, Vol. 32, No. 2, pp.149-162.

Buttle, F. (1996), "Relationship marketing", in Buttle, F. (Ed.), Relationship Marketing: Theory and Practice, Paul Chapman Publishing, London, pp. 1-16.

Capon, N. and Glazer, R. (1987), "Marketing and technology: a strategic coalignment", Journal of Marketing, Vol. 51, No. 3, pp. 1-14.

Christopher, M., Payne, A. and Ballantyne, D. (1991), Relationship Marketing: Bringing quality, customer service, and marketing together, Butterworth-Heinemann, Oxford.

Collins, B. A. (1999), "Pairing relationship value and marketing”, Australasian Marketing Journal, Vol. 7, No. 1, pp. 63-71.

Cram, T. (1994), The Power of Relationship Marketing: How to Keep Customers for Life, Pitman Publishing, London.

Dey, I. (1993), Qualitative Data Analysis: A User-friendly Guide for Social Scientists, Routledge, London. 
Dodge, H. R. and Fullerton, S. (1997), "From exchanges to relationships: a reconceptualization of the marketing paradigm", Journal of Marketing Theory and Practice, Vol. 5, No. 2, pp. 1-7.

Dutta, S., Narasimhan, O. and Rajiv, S. (1999), "Success in high-technology markets: is marketing capability critical”, Marketing Science, Vol. 18, No. 4, pp. 547-568.

Dwyer, F. R., Schurr, P. H. and Oh, S. (1987), "Developing buyer-seller relationships", Journal of Marketing, Vol. 51, No. 2, pp. 11-27.

Eisenhardt, K. M. (1989), "Building theories from case study research" Academy of Management Review, Vol. 14, No. 4, pp. 532-550.

Fearne, A. and Hughes, D. (1999), Success Factors in the Fresh Produce Supply Chain: Some Examples from the UK, Food Industry Management Group, Wye College, Ashford.

Fontenot, R. J. and Wilson, E. J. (1997), "Relational exchange: a review of selected models for a prediction matrix of relationship activities", Journal of Business Research, Vol. 39, No. 1, pp. 5-12.

Galizzi, G. and Venturini, L. (Eds.) (1996), Economics of Innovation: The Case of the Food Industry, Physica-Verlag, Heidelberg.

Glazer, R. (1991), "Marketing in an information-intensive environment: strategic implications of knowledge as an asset", Journal of Marketing, Vol. 55, No. 4, pp. 1-19.

Gordon, I. (1998), Relationship Marketing: New Strategies, Techniques and Technologies to Win the Customers You Want and Keep Them Forever, John Wiley \& Sons, Toronto.

Grönroos, C. (1994), "Quo vadis, marketing? Toward a relationship marketing paradigm”, Journal of Marketing Management, Vol. 10, No. 5, pp. 347-360.

Gummesson, E. (1997), "Emerging approaches to return on relationships", in Christopher, M. and Payne, A. (Eds.), Proceedings of the 5th International Colloquium in Relationship Marketing, Cranfield School of Management, Cranfield, pp. 9-23. 
Gummesson, E. (1998), "Total relationship marketing: experimenting with a synthesis of research frontiers", competitive paper for the 6th International Colloquium in Relationship Marketing, 7-8 December, University of Auckland, Auckland.

Gummesson, E. (1999), Total Relationship Marketing: From the 4Ps - product, price, promotion, place - of traditional marketing management to the $30 \mathrm{Rs}$ - the thirty relationships - of the new marketing paradigm, Butterworth-Heinemann, Oxford.

Harker, M. J. (1999), "Relationship marketing defined? An examination of current relationship marketing definitions", Marketing Intelligence \& Planning, Vol. 17, No. 1, pp. 13-20.

Hughes, D. (Ed.) (1994), Breaking With Tradition: Building Partnerships \& Alliances in the European Food Industry, Wye College Press, Wye.

Jackson, B. B. (1985), Winning and Keeping Industrial Customers, Lexington Books, Lexington, Massachusetts.

Jaworski, B. J. and Kohli, A. K. (1993), "Market orientation: antecedents and consequences”, Journal of Marketing, Vol. 57, No. 3, pp. 53-70.

Jüttner, U. and Wehrli, H. P. (1994), "Relationship marketing from a value system perspective”, International Journal of Service Industry Management, Vol. 5, No. 5, pp. 5473.

Lewin, J. E. and Johnston, W. J. (1997), "Relationship marketing theory in practice: a case study", Journal of Business Research, Vol. 39, No. 1, pp. 23-31.

Lincoln, Y. S. and Guba, E. (1985), Naturalistic Inquiry, Sage Publications, Beverly Hills, California.

Lindgreen, A. (2001), "A framework for studying relationship marketing dyads", Qualitative Market Research - An International Journal, Vol. 4, No. 2, pp. 75-87. 
Lindgreen, A. and Crawford, I. (1999), "Implementing, monitoring and measuring a programme of relationship marketing", Marketing Intelligence \& Planning, Vol. 17, No. 5, pp. 231-239.

Lindgreen, A. and Pels, J. (2000), "Marketing exchange situations: empirical cases from the seller's perspective", in Gummesson, E., Liljegren, G. and Feurst, O. (Eds.), Proceedings of the 8th International Colloquium in Relationship Marketing: Return on Relationships, 7-9 December, Stockholm University, Stockholm.

Marketing Science Institute (1999), Research: The 1998-2000 Research Priorities, http://www.msi.org/msi/res01.htm.

McKenna, R. (1991), Relationship Marketing: Own the market through strategic customer relationships, Century Business, London.

Miles, B. and Huberman, A. M. (1994), Qualitative Data Analysis: An Expanded Sourcebook, 2nd ed., Sage Publications, Thousand Oaks, California.

Mohr, J. and Spekman, R. (1994), "Characteristics of partnership success: partnership attributes, communication behavior, and conflict resolution techniques", Strategic Management Journal, Vol. 15, No. 2, pp. 135-152.

Morgan, R. M. and Hunt, S. D. (1994), "The commitment-trust theory of relationship marketing”, Journal of Marketing, Vol. 58, No. 3, pp. 20-38.

Möller, K. and Halinen-Kaila, A. (1998), "Relationship marketing: its disciplinary roots and future directions", in Andersson, P. (Ed.), Proceedings of the 27th Annual Conference of the European Marketing Academy, Elanders Gotab, Stockholm, Vol. 1, pp. 289-310.

Palmer, A. (1994), "Relationship marketing: back to basics?" Journal of Marketing Management, Vol. 10, pp. 571-579.

Palmer, A. (1998), Principles of Services Marketing, 2nd ed., McGraw-Hill, London. 
Peppers, D. and Rogers, M. (1995), “A new marketing paradigm: share of customer, not market share", Planning Review, Vol. 23, No. 2, pp. 14-18.

Punch, K. F. (1998), Introduction to Social Research: Quantitative and Qualitative Approaches, Sage Publications, Thousand Oaks, California.

Reichheld, F. F. (1996), The Loyalty Effect: The Hidden Force Behind Growth, Profits, and Lasting Value, Harvard Business School Press, Boston, Massachusetts.

Rosenberg, L. J. and Czepiel, J. A. (1984), “A marketing approach for customer retention”, Journal of Consumer Marketing, Vol. 1, No. 2, pp. 45-51.

Sharma, A. and Sheth, J. N. (1997), "Relationship marketing: an agenda for inquiry", Industrial Marketing Management, Vol. 26, pp. 87-89.

Sheth, J. N. and Parvatiyar, A. (Eds.) (2000), Handbook of Relationship Marketing, Sage Publications, Thousand Oaks, California.

Sheth, J. N. and Sharma, A. (1997), "Supplier relationships: emerging issues and challenges", Industrial Marketing Management, Vol. 26, pp. 91-100.

Snehota, I. and Söderlund, M. (1998), "Relationship marketing - what does it promise and what does it deliver? An empirical examination of repeat purchase customers", in Andersson, P. (Ed.), Proceedings of the 27th Annual Conference of the European Marketing Academy, Elanders Gotab, Stockholm, Vol. 1, pp. 311-330.

Söderlund, M. and Johansson, J. K. (1997), "Do markets become more fragmented over time? A literature review and an empirical test", Proceedings of the 26th Annual Conference of the European Marketing, 20-20 May, Warwick Business School, Warwick. Traill, B. and Pitts, E. (Eds.). (1998), Competitiveness in the Food Industry, Blackie A\&P, London. 
Vlosky, R. P. and Wilson, E. J. (1997), "Partnering and traditional relationships in business marketing: an introduction to the special issue”, Journal of Business Research, Vol. 39, No. 1, pp. 1-4.

Wilson, N. (1996), “The supply chains of perishable products in northern Europe”, British Food Journal, Vol. 98, No. 6, pp. 9-15.

Wilson, E. J. and Vlosky, R. P. (1997), "Partnering relationship activities: building theory from case study research”, Journal of Business Research, Vol.39, No. 1, pp.59-70. .

Yin, R. K. (1994), Case Study Research: Design and Methods, 2nd ed., Sage Publications, Thousand Oaks, California. 


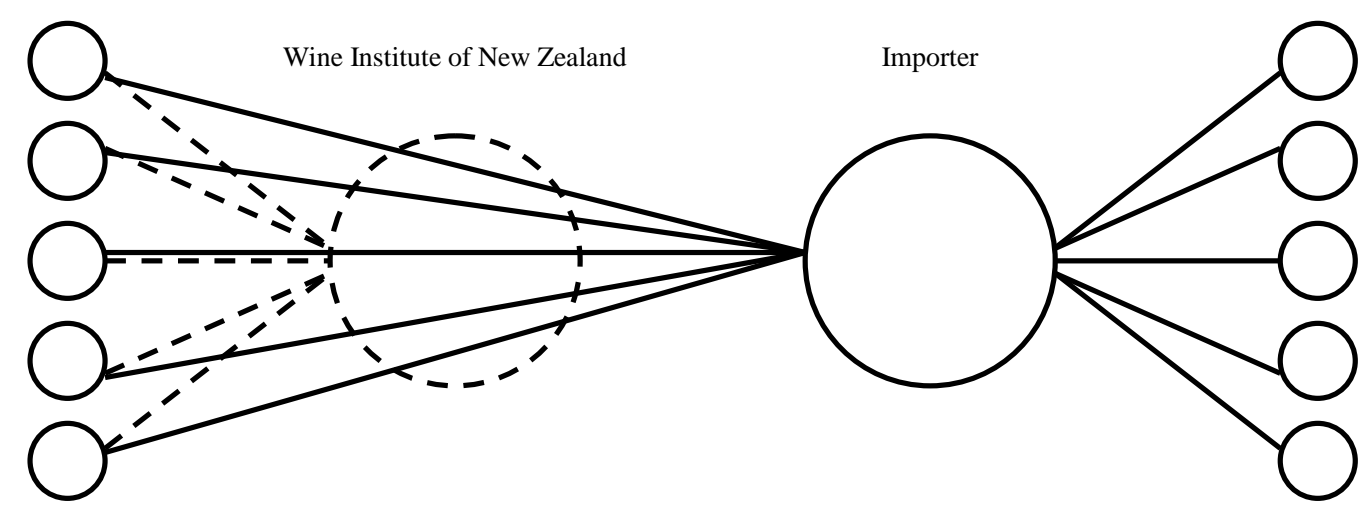

Figure 1. Relationships in the New Zealand-British wine supply chain 
Table 1. Attributes of marketing exchanges, characterised as transactional and relational respectively

\begin{tabular}{|c|c|c|}
\hline Attribute & $\begin{array}{l}\text { Transactional marketing } \\
\text { exchange }\end{array}$ & $\begin{array}{l}\text { Relational marketing } \\
\text { exchange }\end{array}$ \\
\hline Actors & $\begin{array}{l}\text { The buyer has a generic need while } \\
\text { the seller has a generic offer }\end{array}$ & $\begin{array}{l}\text { The buyer has a particular need and } \\
\text { the seller has a unique offer }\end{array}$ \\
\hline Nature of marketing exchange & $\begin{array}{l}\text { The products or services are } \\
\text { standardised }\end{array}$ & $\begin{array}{l}\text { The products or services are } \\
\text { customised }\end{array}$ \\
\hline Interaction between actors & $\begin{array}{l}\text { The interaction between actors are } \\
\text { characterised in terms of, for } \\
\text { example, power, conflict, and } \\
\text { control }\end{array}$ & $\begin{array}{l}\text { The interaction between actors are } \\
\text { characterised in terms of, for } \\
\text { example, trust, commitment, and } \\
\text { co-operation }\end{array}$ \\
\hline Duration of marketing exchange & $\begin{array}{l}\text { The duration of marketing } \\
\text { exchanges is independent and } \\
\text { discrete }\end{array}$ & $\begin{array}{l}\text { The duration of marketing } \\
\text { exchanges is episodic in a series of } \\
\text { episodes (i.e., on-going) }\end{array}$ \\
\hline Structural attributes of market place & $\begin{array}{l}\text { The structural attributes of market } \\
\text { place is characterised as an } \\
\text { anonymous and efficient market }\end{array}$ & $\begin{array}{l}\text { The structural attributes of market } \\
\text { place is characterised in terms of } \\
\text { numerous networks to a network } \\
\text { approach }\end{array}$ \\
\hline Marketing approach & The marketing approach is the $4 \mathrm{Ps}$ & $\begin{array}{l}\text { The marketing approach is } \\
\text { marketing through relationships, } \\
\text { networks, and interactions }\end{array}$ \\
\hline
\end{tabular}

Source: Lindgreen, A. (2001), “Le paysage du marketing en mutation”, Der Marketeer, October, p. 5. 
Table 2. Relationship marketing as suggested in the marketing literature

\begin{tabular}{lll}
\hline $\begin{array}{l}\text { Nature of relationship } \\
\text { marketing }\end{array}$ & $\begin{array}{l}\text { Implementation of } \\
\text { relationship marketing }\end{array}$ & $\begin{array}{l}\text { Monitoring and measurement } \\
\text { of relationship marketing }\end{array}$ \\
\hline
\end{tabular}

To establish, maintain, and enhance buyer-seller relationships (Jackson, 1985)

To identify individual customers (segments) and to create relationships with these customers (segments) (Gordon, 1998)

To use up-to-date knowledge of individual customers (segments) in order to customise products and services (Cram, 1994)

To increase the share of the customers' total purchasing (Peppers and Rogers, 1995)

To establish relationships, networks, and interactions with important markets (Gummesson, 1999)
Customisation of market communications: developments in information technology have made personalised marketing relationships possible such as database marketing and direct marketing (McKenna, 1991)

Customisation of products: the fragmentation and heterogeneity of goods and services demands are best matched by a corresponding fragmentation on the supply side (Söderlund and Johansson, 1997)

Customer caring: organisations should strive to care, and delight, their customers (Rosenberg and Czepiel, 1984)

Loyalty programmes: organisations should do business with those customers who are loyal and profitable (Reichheld, 1996)

Internal marketing: every person within an organisation has a supplier and customer, and this is why all employees should understand the organisation's mission, strategy, and goals (Christopher, Payne, and Ballantyne, 1991)

Catch-all phrase: some programmes seek to incorporate almost every marketing discipline (Morgan and Hunt, 1994)
Loyalty accounting matrix: a customer's satisfaction with the organisation and his attraction to the organisation are measured; the result is one of four different types of customers (Lindgreen and Crawford, 1999)

Customer loyalty ladder: the market can be divided into prospects, terrorists, defectors, customers, clients, supporters, advocates, and partners (Christopher, Payne, and Ballantyne, 1991)

Customer retention and defection: these figures measure how many customers an organisation keeps and loses (Reichheld, 1996)

Share of customer: this figure indicates how much of a customer's overall purchasing is placed with a given organisation (Peppers and Rogers, 1995)

Intellectual capital: this figure seeks to measure the employees' knowledge, behaviour, motivation, relationships, and networks, as well as relationships that are tied to culture, systems, contracts, image, and the network to which the organisation belongs (Gummesson, 1997) Source: The information, which appears in the table, has been collected from numerous journal articles, but also books. In order not
to overload the table with references to journal articles and books it was decided only to give a rough idea of the variety of sources. 
Table 3. Research findings for the fresh produce sector

\begin{tabular}{|c|c|c|c|}
\hline Research issue & Findings & Findings, continued & Findings, continued \\
\hline Nature of relationship marketing & $\begin{array}{l}\text { Relationship marketing terminology } \\
\text { Widespread criticism of 'partnership'/ 'relationship' } \\
\text { terms as lacking substance and a PR 'gimmick'. There is } \\
\text { a belief that terms do not do justice to a genuine desire } \\
\text { for close working relationship from suppliers. } \\
\text { Power-dependency } \\
\text { Power is imbalanced in favour of retail buyers, but this is } \\
\text { no barrier to entry to suppliers wanting to serve powerful } \\
\text { multiple retailers. A relationship approach does create } \\
\text { inclusive relationships, but these are not necessarily 'two- } \\
\text { way'. } \\
\text { Exclusivity } \\
\text { Retail buyers desire exclusivity. Suppliers are keen to be } \\
\text { selected for exclusive supply relationships. In reality } \\
\text { what emerges is a product 'line' rather than whole } \\
\text { company exclusivity. }\end{array}$ & $\begin{array}{l}\text { Organisational size } \\
\text { Larger suppliers are more desirable to buyers in } \\
\text { partnership. However, large powerful buyers will form } \\
\text { close relationships with small (SME) and specialist } \\
\text { suppliers for reasons of securing exclusivity of product } \\
\text { innovation/ service. } \\
\text { Importance of sector type to relationship forming } \\
\text { Suppliers believe fresh produce to be a 'special' sector } \\
\text { due to its nature (highly perishable, and subject to the } \\
\text { vagaries of climate and pests). However, many suppliers } \\
\text { argue that it is this very nature, which realises close } \\
\text { relationships. }\end{array}$ & $\begin{array}{l}\text { Trust } \\
\text { There is recognition of the importance of mutual trust and } \\
\text { displayed behaviour, e.g. involving shared confidential } \\
\text { information. Suppliers are willing to commit, but buyers } \\
\text { often still withhold commitment in order to hold the } \\
\text { balance of power. } \\
\text { Conflict } \\
\text { There is evidence that partnerships in fresh produce allow } \\
\text { a greater possibility of conflict resolution. However, if } \\
\text { 'flashpoint' issues of quality and service are not quickly } \\
\text { resolved - the buyer may terminate a relationship. } \\
\text { Satisfaction and social bonding } \\
\text { Fresh produce is a 'people' industry, which relies on } \\
\text { good 'social' relationships. However, either party does } \\
\text { not encourage socialising. }\end{array}$ \\
\hline $\begin{array}{l}\text { Implementation of relationship } \\
\text { marketing }\end{array}$ & $\begin{array}{l}\text { Marketing communications } \\
\text { Importance of electronic communications. Use as a two- } \\
\text { way relationship tool is developing. However, there is } \\
\text { evidence that electronic communication has reduced both } \\
\text { the important human interface and 'bargaining power' of } \\
\text { the supplier. } \\
\text { Product customisation } \\
\text { Partner shipping allows development of 'exclusive' } \\
\text { customised products and services to buyers. It facilitates } \\
\text { innovation. There is a tendency towards 'sealed' } \\
\text { production sites dedicating product to a principal } \\
\text { customer. }\end{array}$ & $\begin{array}{l}\text { Product driven versus market driven } \\
\text { A relationship approach has reduced production } \\
\text { orientation in fresh produce. Network supply chains and a } \\
\text { quality orientation provide a more even annual cycle of } \\
\text { production, tailored to meet demand. }\end{array}$ & $\begin{array}{l}\text { Internal marketing } \\
\text { Enthusiasm 'at the top' of organisations for the } \\
\text { theoretical base of relationship marketing is not always } \\
\text { employed internally. } \\
\text { Customer partnering } \\
\text { Close and sometimes 'exclusive' partnerships exist } \\
\text { between suppliers and buyers, driven by the initiative of } \\
\text { retail buyers. However, 'contractual' agreements are } \\
\text { rare. }\end{array}$ \\
\hline $\begin{array}{l}\text { Monitoring and measurement of } \\
\text { relationship marketing }\end{array}$ & $\begin{array}{l}\text { Formal monitoring and measurement } \\
\text { Formalised relationships exist between 'partner' } \\
\text { organisations, this takes the form of more regular and } \\
\text { formal contact. However, written formalised 'partner' } \\
\text { contracts are not prevalent. } \\
\text { Grading of supplier performance } \\
\text { Retail buyers have systems of formalised grading of } \\
\text { performance of suppliers. Suppliers may also be graded } \\
\text { in terms of relationship status and are treated differently. }\end{array}$ & $\begin{array}{l}\text { Returns on relationship marketing } \\
\text { A relationship marketing approach can be a 'fast track' } \\
\text { and explosive growth. However, there is a downward } \\
\text { pressure on profitability even for partner suppliers, with } \\
\text { the burden of investment costs born by the supplier. } \\
\text { Benefits are in the stability of consistent payment from } \\
\text { 'partner' buyers and reduction in supply chain costs } \\
\text { associated with serving one or few partner customers. }\end{array}$ & \\
\hline
\end{tabular}


Table 4. Research findings for the wine sector

\begin{tabular}{|c|c|c|c|}
\hline Research issue & Findings & Findings, continued & Findings, continued \\
\hline Nature of relationship marketing & $\begin{array}{l}\text { Relationship marketing terminology } \\
\text { To be market driven; to be product driven; to build and } \\
\text { develop brand personality and loyalty; to attract, retain } \\
\text { and develop customer relationships; to implement close } \\
\text { partnerships. } \\
\text { Power dependency } \\
\text { Several markets to reduce dependency; same size of } \\
\text { importer and retailer; agreement instead of dictation. } \\
\text { Exclusivity } \\
\text { Importer will not carry similar wines from the same } \\
\text { country. }\end{array}$ & $\begin{array}{l}\text { Organisational size } \\
\text { Often, close personal relationships between small actors; } \\
\text { formal guidelines for relationships between big actors. } \\
\text { Trust in credibility } \\
\text { Awards at wine competitions: prominent position within } \\
\text { sector; in-depth knowledge of sector; affiliation with } \\
\text { third parties. } \\
\text { Trust in benevolence } \\
\text { Frequent forthright communication; importer locates } \\
\text { retailers for exporter; business deal closed by shaking } \\
\text { hands. }\end{array}$ & $\begin{array}{l}\text { Commitment } \\
\text { Partner is given the benefit of the doubt; help partner } \\
\text { reach agreed objectives. } \\
\text { Conflict } \\
\text { Occasionally conflicting views; ability to see it from } \\
\text { partner's side. } \\
\text { Social bonding } \\
\text { Close and personal relationships; friendships; operation } \\
\text { within a closed network. }\end{array}$ \\
\hline $\begin{array}{l}\text { Implementation of relationship } \\
\text { marketing }\end{array}$ & $\begin{array}{l}\text { Market communications } \\
\text { Generic export marketing strategies through the Wine } \\
\text { Institute of New Zealand; press coverage in international } \\
\text { wine journals. } \\
\text { Product customisation } \\
\text { Although most vineyards offer only a range of standard } \\
\text { wines, some vineyards customise their wines, such as } \\
\text { special labels (e.g., for the British retailer Tesco) or } \\
\text { particular brands for a certain market (e.g., Dunlevy } \\
\text { wines for Waiheke Island, New Zealand). }\end{array}$ & $\begin{array}{l}\text { Customer partnering } \\
\text { A vineyard does typically not partner with its customers, } \\
\text { although they do co-operate; only one vineyard (Corbans } \\
\text { Wines) had entered into a formalised partnership with the } \\
\text { importer. } \\
\text { Customer care } \\
\text { Listening to the customers and asking for their advice. }\end{array}$ & $\begin{array}{l}\text { Network } \\
\text { At times, a vineyard will not move outside of its business } \\
\text { network but will rely upon its partners' advice on } \\
\text { possible appropriate importers when it moves into a new } \\
\text { market. } \\
\text { Product or market driven } \\
\text { There were conflicting views among the vineyards } \\
\text { whether the best strategy is to be driven by one's product } \\
\text { or the market. }\end{array}$ \\
\hline $\begin{array}{l}\text { Monitoring and measurement of } \\
\text { relationship marketing }\end{array}$ & $\begin{array}{l}\text { Formal monitoring and measurement plans } \\
\text { For smaller vineyards, the monitoring and measurement } \\
\text { of relationship marketing is very limited; for bigger } \\
\text { vineyards, both monitoring - in terms of production, } \\
\text { logistics, marketing and sales planning - and measuring - } \\
\text { in terms of financial performance reviews - is used more } \\
\text { frequently. } \\
\text { Meetings on performance } \\
\text { Regular meetings between the vineyard and the importer } \\
\text { (i.e., meeting between different employees at different } \\
\text { levels within the organisations); meetings cover } \\
\text { production, inventory, advertising, sales (overall and for } \\
\text { individual brands); both parties can initiate such } \\
\text { meetings. }\end{array}$ & $\begin{array}{l}\text { Responsible parties } \\
\text { The vineyard is responsible for the wine production and } \\
\text { for the logistics (transportation of wine cases from New } \\
\text { Zealand to the British importer) whereas the importer is } \\
\text { responsible for the trading activities in Britain. Both } \\
\text { parties are responsible for the marketing activities and } \\
\text { carry out different parts of these activities. } \\
\text { Returns on relationship marketing } \\
\text { Some vineyards believe that they profit on having a } \\
\text { relational approach to marketing and that they would } \\
\text { suffer not having this approach; other vineyards can } \\
\text { actually measure an increased profit after having installed } \\
\text { such a programme; the profit may be increased retention } \\
\text { of one's business parties. }\end{array}$ & \\
\hline
\end{tabular}




\section{Autobiographical Notes}

Adam Lindgreen: After graduating in Chemistry, Engineering and Physics, Adam Lindgreen finished an MSc at the Technical University of Denmark; an MBA at the University of Leicester in England; and a One Year Postgraduate Programme at the Hebrew University of Jerusalem in Israel, after which he worked as a consultant for Andersen Consulting. He then completed a PhD at Cranfield University in England - with 18 months as a Visiting Research Fellow at the University of Auckland in New Zealand. He is now with the Technical University of Eindhoven in the Netherlands, as well as a Visiting Professor with Auckland University of Technology in New Zealand a Visiting Reader with Harper Adams University College in England. Dr Adam Lindgreen has carried out consulting work for a number of organisations, in Denmark and abroad. He is particularly interested in food and beverage products marketing; customer relationship management (CRM); relationship marketing; customer loyalty; e-business; and Internet marketing. He has published in several international journals and received three best paper awards at international marketing conferences.

Contact details: Adam Lindgreen, Avenue du Centre Sportif 45, Bte 8, 1300 Wavre, Belgium. Email Adam_Lindgreen@hotmail.com. Telephone + 32 - 10222743.

Martin Hingley: Martin Hingley is senior lecturer in Marketing at Harper Adams University College, in Shropshire, the United Kingdom. His primary interests of teaching and research are in the applied areas of agricultural and food industry marketing and supply chain management. Martin Hingley holds a first degree from the University of Newcastle upon Tyne and a higher degree from Cranfield University. He has wide ranging business experience in the agricultural and food industries and spent some time in provision of market 
and business analysis and industry based training with the Institute of Grocery Distribution (IGD). Martin Hingley is currently the Tesco Teaching Fellow at Harper Adams.

Contact details: Martin Hingley, School of Management, Harper Adams University College, Newport, Shropshire, TF10 8NB, United Kingdom. Email mhingley@harper-adams.ac.uk. Telephone + 44 - (0) 1952820 280. Fax + 44 - (0) 1952814783 . 